\title{
Hubungan Faktor Risiko Dermatitis Kontak pada Petani
}

\section{Relationship between Contact Dermatitis Risk Factors for Farmers}

\author{
Achisna Rahmatika ${ }^{1}$, Fitria Saftarina ${ }^{2}$, Dwi Indria Anggraini ${ }^{3}$, Diana Mayasari ${ }^{4}$ \\ Fakultas Kedokteran, Universitas Lampung, Indonesia
}

\section{ARTICLE INFO}

\begin{tabular}{l} 
Article history: \\
Received date \\
24 Mar 2020 \\
Revised date \\
03 Apr 2020 \\
09 Apr 2020 \\
Accepted date \\
07 May 2020 \\
\hline
\end{tabular}

\section{Keywords:}

Contact dermatitis;

Farmers;

Risk factors.

\section{Kata kunci:}

Dermatitis kontak;

Petani;

Faktor risiko.

\author{
ABSTRACT/ ABSTRAK
}

\begin{abstract}
About $30 \%$ of occupational diseases in farmers are contact dermatitis. Contact dermatitis due to work in the agricultural sector is the main commodity in Lampung Province at $35,82 \%$. Farmers are generally always exposed to chemicals in the form of pesticides and fertilizers which can be irritants and allergens. This research was an observational descriptive using a cross-sectional method with 379 respondents. The research data were taken from interviews, questionnaires, and physical examinations by dermatologists and genitals. Data were analyzed using the chi-square test. Results: $13,5 \%$ of farmers experienced contact dermatitis. The analysis results of this study indicate that there is a statistical relationship between contact dermatitis with the use of the following factors, personal protective equipment ( $p$-value $=0,000)$, contact time ( $\mathrm{p}$-value $=0,000$ ), personal hygiene ( $\mathrm{p}$-value $=0,000)$, total types of pesticides $(p$-value $=0,000)$, and number of types of fertilizer $(p$-value $=0,000)$. While the factors that were not statistically significant in this study were the relationship between contact dermatitis and length of service ( $p$-value $=0,919)$, atopic history ( $p$ value $=0,784)$, and type of occupation $(p$-value $=0,115)$. There is a relationship between the following factors such as the use of personal protective equipment, duration of contact, personal hygiene, the number of pesticides, and the number of types of fertilizers with the incidence of contact dermatitis in farmers in the District of Punduh pedada.
\end{abstract}

Sekitar $30 \%$ penyakit okupasi pada petani adalah dermatitis kontak. Dermatitis kontak akibat kerja pada sektor pertanian merupakan komoditas utama di Provinsi Lampung yaitu sebesar $35,82 \%$. Petani umumnya selalu terpapar dengan bahan kimia berupa pestisida dan pupuk yang dapat bersifat sebagai zat iritan dan alergen. Penelitian ini merupakan deskriptif observasional menggunakan metode cross sectional dengan 379 responden. Data penelitian diambil dari wawancara, pengisian kuesioner, dan pemeriksan fisik oleh dokter spesialis kulit dan kelamin. Data dianalisis menggunakan uji chi-square. Sebanyak $13,5 \%$ petani mengalami dermatitis kontak. Hasil uji analisi penelitian ini menunjukkan bahwa adanya hubungan secara statistik antara dermatitis kontak dengan penggunaan faktor-faktor berikut, alat pelindung diri (nilai $p$-value $=0,000$ ), lama kontak (nilai $p$-value $=0,000$ ), personal hygiene (nilai $p$-value $=0,000$ ), jumlah jenis pestisida (nilai $p$-value $=0,000$ ), dan jumlah jenis pupuk (nilai $p$-value $=0,000$ ). Sedangkan faktor-faktor yang tidak bermakna secara statistik dalam penelitian ini adalah hubungan antara dermatitis kontak dengan masa kerja (nilai $p$-value $=0,919$ ), riwayat atopik (nilai $p$ value $=0,784$ ), dan jenis pekerjaan (nilai $p$-value $=0,115$ ). Terdapat hubungan antara faktor-faktor berikut seperti penggunaan alat pelindung diri, lama kontak, personal hygiene, jumlah jenis pestisida dan jumlah jenis pupuk dengan kejadian dermatitis kontak pada petani di Kecamatan Punduh pedada.

Corresponding Author:

Achisna Rahmatika

Fakultas Kedokteran, Universitas Lampung, Indonesia

Email: rahmatikaachisna@gmail.com

\section{PENDAHULUAN}

Dermatitis kontak merupakan inflamasi atau peradangan pada kulit yang diakibatkan oleh kontak langsung dengan substansi yang menyebabkan reaksi inflamasi atau alergi. Dermatitis kontak sering dihubungkan dengan pekerjaan juga disebut sebagai dermatitis kontak akibat kerja (Retnoningsih, 2017). Sekitar 90\% 
dermatitis akibat kerja merupakan dermatitis kontak (Darwadi, Susmiati, \& Lutfhi, 2017).

Timbulnya penyakit dermatitis kontak akibat kerja diakibatkan oleh dua faktor, yaitu faktor endogen dan faktor eksogen. Faktor endogen tersebut meliputi faktor-faktor yang ada pada individu seperti, genetik, jenis kelamin, umur, etnis, tipe kulit, dan riwayat atopi (Djuanda, et al., 2016). Faktor eksogen yang menyebabkan timbulnya dermatitis kontak akibat kerja adalah sifat-sifat bahan kimia iritan seperti keadaan fisik, konsentrasi, jumlah, polarisasi, ionisasi, bahan pembawa dan kelarutan (Wijaya, Darmada, \& Ruyati, 2016).

Bahan kimia berupa pestisida merupakan salah satu penyebab penyakit kulit akibat kerja (Sharma, et al., 2018). Petani terpapar pestisida mulai dari pencampuran pestisida sampai panen tanaman yang sebelumnya dirawat. Selain terpapar pestisida, pupuk juga sering dikaitan dengan dermatitis kontak dan dermatitis kontak akibat kerja baik di industri dan pertanian. Sebuah kasus pada petani berupa reaksi akut terhadap kalsium amonium nitrat yang merupakan kandungan dari pupuk urea (Loukil, Mallem, \& Boulakoud, 2015). Penelitian lainnya yang dilakukan oleh Suryani terhadap petani sawah, menyatakan bahwa masa kerja, penggunaan alat pelindung diri, riwayat penyakit kulit dan personal hygiene merupakan faktor resiko terjadinya dermatitis kontak pada petani sawah (Suryani, Martini, \& Susanto, 2017).

Data epidemiologi di Indonesia memperlihatkan bahwa 97\% dari 389 kasus penyakit kulit adalah dermatitis kontak, sebanyak 66,3\% dari kasus tersebut adalah dermatitis kontak iritan dan 33,7\% adalah dermatitis kontak alergi. National Institutes of Health menyatakan bahwa dermatitis kontak akibat kerja banyak terjadi pada petani. Sekitar 30\% penyakit okupasi pada petani adalah dermatitis kontak (Thomsen, 2014). Sektor pertanian merupakan komoditas utama di Provinsi Lampung yaitu sebesar 35,82\% (Dinas Pertanian Propinsi Lampung, 2015).

Sampai saat ini belum ada data epidemiologi yang menunjukkan gambaran dermatitis kontak pada petani Lampung. Sehingga berdasarkan latar belakang diatas peneliti tertarik untuk meneliti kejadian dermatitis kontak dan hubungannya terhadap faktor risiko pada petani di Lampung.

\section{METODE}

Penelitian ini merupakan penelitian deskriptif observasional dengan pendekatan cross sectional. Dilaksanakan di Kecamatan Punduh Pedada Kabupaten Pesawaran Provinsi Lampung, pada Agustus-Desember 2018. Sampel penelitian adalah seluruh petani pada kecamatan punduh pedada yaitu 379 orang, sampel diambil dengan menggunakan metode proportional random sampling. Proportional disini menggambarkan lokasi tempat tinggal sebagian petani. Kriteria inklusi pada penelitian ini, berusia antara 18 s.d 60 tahun dan bersedia mengikuti penelitian ini. Kriteria esklusi adalah responden yang sedang dalam pengobatan dengan obat kulit topikal (neomisin topikal, antibiotik topikal, krim steroid, anthistamin topikal, obat topikal dengan kandungan parabens atau lanolin).

Prosedur penelitian ini berupa pengambilan data primer yang dilakukan dengan memberikan kuesioner skrining dan penelitian meliputi jenis faktor risiko yang terpapar kepada responden yang diambil dari penelitian Marcherya (Marcherya, 2018) dan Suryani (Suryani, et al., 2017) dan data sekunder yang diperoleh dari Dinas pertanian kabupaten Pesawaran provinsi Lampung. Penegakan diagnosis dermatitis kontak dilakukan oleh dokter spesialis kulit dan kelamin. Analisis bivariat pada penelitian ini menggunakan uji statistik Chisquare. Penelitian ini telah lulus persetujuan etik dengan No: 043/UN26.18/PP.05.02.00/2019.

\section{HASIL}

Total penduduk di Kecamatan Punduh Pedada Kabupaten Pesawaran Provinsi Lampung adalah 16.079 jiwa dengan jumlah laki-laki sebanyak 8.283 jiwa dan jumlah penduduk perempuan sebanyak 7.796 jiwa. Jumlah petani sebesar 2202 petani. Pada penelitian ini subjek penelitian berjumlah 379 orang dimana 227 adalah laki-laki dan 152 orang lainnya adalah perempuan subjek penelitian terbagi kedalam 4 kelompok usia pada rentan usia 18-25 tahun terdapat 13 orang, $25-35$ tahun terdapat 72 orang, 30-45 tahun 211 orang dan rentan usia 46-60 tahun terdapat 83 orang. Semua responden penelitian merupakan petani yang aktif terpapar zat iritan seperti pestisida dan pupuk setiap harinya.

Faktor risiko yang dinilai berdasarkan kuisioner meliputi penggunaan alat pelindung diri (APD) yaitu penggunaan alatpelindung diri berupa alaskaki, sarungtangan serta kaos lengan panjang dan celana panjang oleh petani di tempat kerja saat melakukan tugasnya dengan pemberian poin 0 tidak lengkap, 1 sebagian lengkap dan 2 lengkap. Lama kontak yaitu lama pekerja kontak 
denganbahan kimiadalam satu harikerja, dinilai menggunakan skoring $0<4$ jam dan $1>4$ jam. Personal hygiene dinilai menggunakan kuesioner menurut Suryani (2011), masa kerja yaitu jangka waktu pertama kali menjadi petani sampai saat dilakukan penelitian, dihitung dalam satuan tahun dengan poin 0 kurang dari 5 tahun dan 1 lebih dari 5 tahun, riwayat atopik dinilai apakah ada riwayat penyakit berikut dermatitis atopik, rhinitis alergi, asma dan konjungtivitis alergi. Jumlah jenis pestisida yaitu jumlah campuran pestisida yang digunakan saat menyemprot tanaman perbulan, dengan angka 0 hanya menggunakan 1 pestisida, 1 lebih dari 1 pestisida. Jumlah jenis pupuk adalah jumlah jenis pupuk yang dilakukan perbulan untuk membantu pertumbuhan tanaman supaya berkembamg dengan baik. Jenis pekerjaan adalah kumpulan pekerjaan yang mempunyai rangkaian tugas yang bersamaan serta menjabarkan secara singkat pekerjaan dari suatu kelompok jenis pekerjaan tertentu seperti petani sawah dan sayur. Karakteristik sampel dapat dilihat pada tabel 1.
Tabel 1. Karakteristik responden

\begin{tabular}{|c|c|c|}
\hline Karakteristik & $\mathbf{n}$ & $\%$ \\
\hline \multicolumn{3}{|l|}{ Jenis Kelamin } \\
\hline Laki-laki & 227 & 59,9 \\
\hline Perempuan & 152 & 40,1 \\
\hline \multicolumn{3}{|l|}{ Usia } \\
\hline 18-25 tahun & 13 & 3,4 \\
\hline 25-35 tahun & 72 & 19 \\
\hline 30-45 tahun & 211 & 55,7 \\
\hline 46-60 tahun & 83 & 21,9 \\
\hline \multicolumn{3}{|l|}{ Penggunaan APD } \\
\hline Tidak Menggunakan & 54 & 14,2 \\
\hline Tidak Lengkap & 150 & 39,6 \\
\hline Lengkap & 175 & 46,2 \\
\hline $\begin{array}{l}\text { Frekuensi Lama Kontak } \\
(<4 \text { jam })\end{array}$ & 263 & 69,4 \\
\hline \multicolumn{3}{|l|}{ Personal hygiene } \\
\hline Tidak Baik & 32 & 8,4 \\
\hline Baik & 69 & 18,2 \\
\hline Sangat Baik & 278 & 73,4 \\
\hline Masa Kerja ( $<5$ tahun) & 50 & 13,2 \\
\hline Riwayat Atopi & 53 & 14 \\
\hline$>1$ jenis pestisida & 126 & 33,2 \\
\hline$>1$ jenis pupuk & 123 & 32,5 \\
\hline \multicolumn{3}{|l|}{ Jenis Petani } \\
\hline Petani Sayur & 206 & 54,4 \\
\hline Petani Sawah & 173 & 45,6 \\
\hline Dermatitis Kontak & 51 & 13,5 \\
\hline
\end{tabular}

Uji hubungan terhadap variabel bebas meliputi, penggunaan APD, lama kontak, personal hygiene, masa kerja, riwayat atopik, jumlah jenis pestisida, jumlah jenis pupuk, serta jenis pekerjaan yaitu petani sawah dan petani sayur terhadap variabel terikat yaitu kejadian dermatitis kontak dengan menggunakan uji Chisquare dapat dilihat di Tabel 2.

Tabel 2. Uji faktor risiko terhadap Dermatitis Kontak

\begin{tabular}{|c|c|c|c|c|}
\hline & Faktor Risiko & $\begin{array}{c}\text { Kejadian Dermatitis } \\
\text { Kontak }(\%)\end{array}$ & p-value & OR $(95 \%$ CI $)$ \\
\hline \multirow{3}{*}{ APD } & Lengkap & 4 & \multirow{3}{*}{$0,00^{*}$} & \multirow{3}{*}{-} \\
\hline & Tidak Lengkap & 16 & & \\
\hline & Tidak Menggunakan & 37 & & \\
\hline \multirow{3}{*}{$\begin{array}{l}\text { Personal } \\
\text { hygiene }\end{array}$} & Tidak Baik & 32,5 & \multirow{3}{*}{$0,00 *$} & \multirow{3}{*}{-} \\
\hline & Baik & 24,6 & & \\
\hline & Sangat Baik & 5 & & \\
\hline \multirow{2}{*}{$\begin{array}{l}\text { Frekuensi } \\
\text { Lama Kontak }\end{array}$} & $\geq 4$ jam & 23,3 & \multirow{2}{*}{$0,00 *$} & 3,021 \\
\hline & $<4$ jam & 9,1 & & $(1,656-5,512)$ \\
\hline \multirow{2}{*}{ Masa Kerja } & $\geq 5$ tahun & 13,7 & \multirow{2}{*}{0,919} & 1,162 \\
\hline & $<5$ tahun & 12 & & $(0,468-2,884)$ \\
\hline \multirow{2}{*}{ Riwayat Atopi } & Ada & 11,3 & \multirow{2}{*}{0,784} & 0,797 \\
\hline & Tidak Ada & 13,8 & & $(0,322-1,973)$ \\
\hline \multirow{2}{*}{$\begin{array}{l}\text { Jumlah Jenis } \\
\text { Pestisida }\end{array}$} & $>1$ jenis & 34,1 & \multirow{2}{*}{$0,00 *$} & 15,866 \\
\hline & 1 jenis & 3,2 & & $(7,167-35,122)$ \\
\hline \multirow{2}{*}{ Jenis pupuk } & $>1$ jenis & 31,7 & \multirow{2}{*}{$0,00^{*}$} & 9,440 \\
\hline & 1 jenis & 4,7 & & $(4,721-18,876)$ \\
\hline Jenis & Petani Sawah & 16,8 & \multirow{2}{*}{$0,00^{*}$} & 1,684 \\
\hline Pekerjaan & Petani Sayur & 10,7 & & $(0,929-3,055)$ \\
\hline
\end{tabular}




\section{PEMBAHASAN}

Alat pelindung diri mempunyai manfaat untuk melindungi bagian tubuh pekerja yang fungsinya melindungi sebagian atau seluruh tubuh dari potensi bahaya paparan dari luar di tempat kerja (Fielrantika \& Dhera, 2018). Hasil analisis bivariat pada penelitian ini didapatkan bahwa petani yang mengalami Dermatitis dan menggunakan APD secara lengkap sebanyak 7 petani (4\%), yang menggunakan APD secara tidak lengkap sebanyak 24 petani (16\%) dan yang tidak menggunakan APD sebanyak 20 petani (37\%). Hasil analisis bivariat menggunakan uji Chi-square didapatkan $p$-value $=0,000 \quad(p$ value $<0,05)$, sehingga dapat disimpulkan bahwa terdapat hubungan yang signifikan secara statistic antara penggunaan APD terhadap dermatitis. Hasil penelitian ini sesuai dengan penelitian yang pernah dilakukan pada petani sawah dan petani garam di Kecamatan Kaliori Kabupaten Rembang, Semarang, bahwa ada hubungan yang siginifikan antara penggunaan APD dengan kejadian dermatitiskontak ( $p$-value $<0,042)$. Kebersihan APD dapat mencegah keparahan kondisi kulit karena keadaan lingkungan kerja yang lembab, sehingga dapat mencegah terjadinya dermatitiskontak. Penelitian lain yang dilakukan oleh Nugroho bahwa kelengkapan memakai APD dan mengganti pakaian setelah menyemprot dapat mempengaruhi petani terkena keluhan kulit (Nugroho \& Sumini, 2015).

Setiap pekerja memiliki lama kontak serta lama paparan yang berbeda-beda, semakin sering kulit individu terpapar bahan iritan dan alergen, maka semakin memungkinkan zat tersebut berpenetrasi ke dalam kulit dan menyebabkan reaksi peradangan kulit (Pradananingrum, Lestantyo, \& Jayanti, 2018). Hasil analisis bivariat pada penelitian ini didapatkan bahwa petani dengan dermatitis yang memiliki lama kontak <4 jam sebanyak 24 orang $(9,1 \%)$ dan yang memiliki lama kontak $\geq 4$ jam sebanyak 27 orang (23,3\%). Hasil analisis bivariat menggunakan uji Chi-square didapatkan $p$ value $=0,000 \quad(p$-value $<0,05)$, sehingga dapat disimpulkan bahwa terdapat hubungan secara statistic antara lama kontak terhadap dermatitis. Di dapatkan pula nilai Odds Ratio (OR) sebesar 3,021 dengan $95 \%$ confidence interval (CI) 1,656-5,512 yang menyatakan bahwa petani yang memiliki lama kontak $\geq 4$ jam memiliki resiko untuk terkena dermatitis 3 kali lebih besar dibandingkan dengan petani yang memiliki lama kontak <4 jam. Hal ini sesuai dengan penelitian serupa yang dilakukan Suryani pada PT. Coesmar Indonesia tahun 2011 pada 50 orang pekerja yang menyimpulkan bahwa terdapat hubungan yang bermakna antara lama kontak dengan kejadian dermatitis kontak ( $p$-value $=0,012) \quad$ (Suryani, 2011).

Personal hygiene merupakan salah satu faktor kejadian dermatitis kontak. Personal hygiene yang dimaksud yaitu kebiasaan mandi, mencuci tangan dan kaki menggunakan air mengalir dan sabun setelah bekerja, serta mencuci pakaian kerja setelah pulang dari kerja. Hasil analisis bivariat pada penelitian ini didapatkan bahwa petani dengan Dermatitis yang memiliki personal hygiene tidak baik sebanyak 20 orang $(32,5 \%)$, yang memiliki personal hygiene baik sebanyak 17 orang $(24,6 \%)$ dan yang memiliki personal hygiene sangat baik sebanyak 14 orang $(5 \%)$. Berdasarkan data tersebut dapat disimpulkan bahwa petani yang mengalami dermatitis lebih banyak pada kelompok petani yang memiliki personal hygiene tidak baik.Hasil analisis bivariat menggunakan uji Chi-square didapatkan $p$-value $=0,000 \quad(p$ value $<0,05)$, sehingga dapat disimpulkan bahwa terdapat hubungan antara Personal hygiene terhadap dermatitis. Penelitian serupa juga dilakukan oleh Pradananingrum, dari hasil uji statistik diketahui bahwa nilai $p$-value $=0,031(p$ value $<0,05)$. Dengan Personal hygiene yang buruk 14 orang $(87,5 \%)$ dan yang baik 9 orang $(52,9 \%)$ (Pradananingrum, et al., 2018).

Masa kerja adalah lamanya responden bekerja sebagai petani, dihitung sejak pertama kali bekerja sampai pada saat penelitian berlangsung. Pekerja lebih lama terpanjan dan berkontak dengan bahan iritan dapat merusak sel kulit bagian luar, semakin lama terpanjan maka akan merusak sel kulit hingga bagian dalam dan akan memudahkan untuk terjadinya dermatitis kontak(F. Suryani, 2011). Pada penelitian ini disimpulkan bahwa petani yang mengalami dermatitis dengan masa kerja $<5$ tahun sebanyak $12 \%$, petani yang mengalami dermatitis dengan masa kerja $\geq 5$ sebanyak $13,7 \%$. Persentase kejadian dermatitis tidak terlalu berbeda pada kelompok masa kerja <5 tahun maupun masa kerja $\geq 5$ tahun.Hasil analisis bivariat menggunakan uji Chi-square didapatkan $p$ value $=0,919$ ( $p$-value $>0,05)$, sehingga dapat disimpulkan bahwa tidak terdapat hubungan yang signifikan secara statistik antara masa kerja terhadap dermatitis. Di dapatkan pula nilai $O d d s$ Ratio (OR) sebesar 1, 162 dengan 95\% confidence interval (CI) 0,468-2,884 yang menyatakan bahwa petani yang memiliki masa kerja $\geq 5$ jam memiliki resiko untuk terkena dermatitis 1,2 kali lebih besar dibandingkan dengan petani yang memiliki masa kerja $>5$ jam. 
Hal ini sejalan dengan penilitian yang dilakukan oleh Indrawan diketahui bahwa dari nilai uji statistik di dapatkan nilai $p$-value $=1,000 \quad(p$ value $>0,05)$, sehingga secara statistik menunjukkan bahwa tidak ada hubungan yang bermakna antara masa kerja dengan kejadian dermatitis kontak iritan pada pekerja bagian premix di PT. X Cirebon. Pekerja dengan pengalaman akan lebih berhati-hati sehingga kemungkinan terpajan bahan kimia lebih sedikit, tenaga kerja yang memiliki masa kerja yang lama akan lebih terampil dan berpengalaman di dalam mengerjakan pekerjaannya sehingga hasilnya akan lebih baik (Indrawan, Suwondo, \& Lestantyo, 2014).

Riwayat atopik juga merupakan salah satu faktor kejadian dermatitis kontak. Istilah atopik menunjukan predisposisi genetik yang akan berkembang menjadi dermatitis atopik, asma, konjungtivitis alergi dan rhinitis alergi (Marcherya, 2018). Hasil analisis bivariat pada penelitian ini didapatkan bahwa petani dengan Dermatitis yang tidak memiliki Riwayat Atopik sebanyak 45 orang $(13,8 \%)$ dan yang memiliki riwayat atopik sebanyak 6 orang $(11,3 \%)$. Berdasarkan data tersebut dapat disimpulkan bahwa petani yang mengalami dermatitis lebih banyak pada kelompok petani yang tidak ada riwayat atopik. Hasil analisis bivariat menggunakan uji Chi-square didapatkan $p$ value $=0,784$ ( $p$-value $>0,05)$, dan Odds Ratio (OR) sebesar 0,797 dengan 95\% confidence interval (CI) 0,322-1,973 sehingga dapat disimpulkan bahwa tidak terdapat hubungan yang signifikan secara statistik antara riwayat atopik terhadap dermatitis sehingga dapat disimpulkan bahwa tidak terdapat hubungan antara riwayat atopik terhadap dermatitis. Hasil ini sesuai dengan penelitian yang dilakukan oleh Septiani diketahui bahwa sebanyak $36,8 \%$ penderita dermatitis kontak memiliki riwayat atopik dan $29,6 \%$ penderita dermatitis kontak tidak memiliki riwayat atopik dengan nilai $p$-value 0,591 , yang menyatakan tidak ada hubungan antara riwayat atopik dengan kejadian dermatitis kontak (Septiani, 2012).

Dalam penelitian ini, peneliti juga meneliti hubungan jumlah jenis pestisida terhadap kejadian dermatitis kontak. Pestisida merupakan bahan kimia yang dapat menjadi salah satu penyebab penyakit kulit, pestisida mengandung lebih dari 2 miliar pon bahan aktif. Beberapa studi penelitian di seluruh dunia mengatakan bahwa dermatitis kontak pada pekerja agrikultur seperti di India, Panama, Taiwan, California berhubungan dengan penggunaan pestisida (Irby, et al., 2009). Penggunaan jumlah jenis pestisida dalam penelitian ini dikategorikan menjadi 2 kelompok yaitu penggunakan 1 jenis pestisida dan $>1$ jenis pestisida. Hasil analisis bivariat pada penelitian ini didapatkan bahwa petani dengan dermatitis yang menggunakan 1 jenis pestisida sebanyak 8 orang $(3,2 \%)$ dan yang menggunakan $>1$ jenis pestisida sebanyak 43 orang $(34,1 \%)$. Berdasarkan data tersebut dapat disimpulkan bahwa petani yang mengalami dermatitis lebih banyak pada kelompok petani yang menggunakan $>1$ jenis pestisida. Hasil analisis bivariat menggunakan uji Chi-square didapatkan $p$-value $=0,000 \quad(p$-value $<0,05)$, sehingga dapat disimpulkan bahwa terdapat hubungan antara jumlah jenis pestisida terhadap dermatitis. Di dapatkan pula nilai Odds Ratio (OR) sebesar 15,886 dengan $95 \%$ confidence interval $(\mathrm{CI})$ 7,167-35,122 yang menyatakan bahwa petani yang menggunakan pestisida $>1$ jenis pestisida memiliki resiko untuk terkena dermatitis 15,9 kali lebih besar dibandingkan dengan petani yang menggunakan 1 jenis pestisida. Penelitian srupa yang dilakukan oleh Guna, dkk dengan uji statistik dengan chi-square, dapat disimpulkan bahwa ada hubungan antara jenis pestisida dengan kejadian dermatitis kontak pada petani padi di Kecamatan Mowewe Kabupaten Kolaka Timur tahun 2017. Setelah uji keeratan hubungan dengan menggunakan koefisien phi (RØ), diperoleh nilai $R \emptyset=0,402$. Angka tersebut menunjukkan hubungan yang sedang karena terletak antara interval 0,26-0,50 (Guna, Lisnawaty, dan Ainurafiq, 2017).

Hasil analisis bivariat pada penelitian ini didapatkan bahwa petani dengan dermatitis yang menggunakan 1 jenis pupuk sebanyak 12 orang (12\%) dan yang menggunakan $>1$ jenis pupuk sebanyak 39 orang $(31,7 \%)$. Berdasarkan data tersebut dapat disimpulkan bahwa petani yang mengalami dermatitislebih banyak pada kelompok petani yang menggunakan $>1$ jenis pupuk. Hasil analisis bivariat menggunakan uji Chi-square didapatkan $p$-value $=0,000 \quad(p$ value $<0,05$ ), sehingga dapat disimpulkan bahwa terdapat hubungan antara Jumlah jenis pupuk terhadap dermatitis. Di dapatkan pula nilai $O d d s$ Ratio (OR) sebesar 9,440 dengan 95\% confidence interval (CI) 4,721-18,876 yang menyatakan bahwa petani yang menggunakan pestisida $>1$ jenis pupuk memiliki resiko untuk terkena dermatitis 9,4 kali lebih besar dibandingkan dengan petani yang menggunakan 1 jenis pupuk. Hal ini sesuai dengan penelitian yang dilakukan oleh Darwandi dkk mengenai hubungan antara kontak pupuk dengan dermatitis pada petani di Desa Sekaran Kabupaten Tuban tahun 2017 didapatkan hasil bahwa ada hubungan antara 
kontak pupuk dengan dermatitis pada petani di kelompok tani Desa Sekaran Kabupaten Tuban Tahun 2017 dengan $p$-value $=0,000$ (Darwadi, et al., 2017).

Pada penelitian ini, peneliti juga mencari hubungan jenis pekerjaan yaitu petani sawah dan petani sayur terhadap kejadian dermatitis kontak. Penelitian yang dilakukan Sudardja (2015) didapatkan prevalensi dermatitis kontak pada petani sayur sebesar $25,7 \%$ dari dermatitis kontak $61,2 \%$ dari 67 petani dimana angka kejadian dermatitis kontak 436 responden dimana resiko kejadian dermatitis kontak dipengaruhi oleh penggunaan pestisida, riwayat atopik dan bentuk formula pestisida yang digunakan (Sudardja, 2015). Berdasarkan data tersebut dapat disimpulkan bahwa petani yang mengalami dermatitislebih banyak pada kelompok petani sawah.Hasil analisis bivariat pada penelitian ini menggunakan uji Chi-square didapatkan $p$ value $=0,115$ ( $p$-value $>0,05)$, sehingga dapat disimpulkan bahwa tidak terdapat hubungan antara jenis pekerjaan terhadap dermatitis. Hal ini sesuai dengan penelitian sebelumnya bahwa tidak ada perbedaan terhadap jenis pekerjaan dengan kejadian dermatitis kontak antara petani garam dan petani sawah di Kecamatan Kaliori Kabupaten Rembang dengan nilai $p$-value $=0,12$ (Suryani, et al., 2017).

Pada penelitian ini masih ada beberapa kekurangan yang menjadi keterbatasan penelitian diantaranya adanya bias informasi antara peneliti dengan responden, terdapat perbedaan asumsi mengenai riwayat atopik bagi responden dibandingkan dengan asumsi dari peneliti. Upaya

\section{DAFTAR PUSTAKA}

Darwadi, Susmiati, \& Lutfhi, E. I. (2017). Hubungan Kontak Pupuk Urea Dengan Dermatitis Kontak Pada Petani Di Desa Sekaran Kabupaten Tuban Tahun 2017. NJS, 1(1), 57-65.

Dinas Pertanian Propinsi Lampung. (2015). Epidemiologi pertanian di propinsi Lampung tahun 2014. (unpublished data).

Djuanda, A., Suriadiredja, A., Sudharmono, A., Wiryadi, B., Kurniati, D., \& Daili, E. (2016). Ilmu Penyakit Kulit dan Kelamin. Jakarta: Fakultas Kedokteran Universitas Indonesia.

Fielrantika, S., \& Dhera, A. (2018). Hubungan karakteristik pekerja, kelengkapan dan higienitas APD dengan kejadian dermatitis kontak. The Indonesian Journal of Occupational Safety and Health, 6(1), 16-26. peneliti untuk menghindari bias ini, diagnosis dermatitis atopik dikonfirmasi dengan pemekrisaan oleh dokter spesialis kulit. Kuesioner yang digunakan masih bersifat luas sehingga jawaban yang didapat tidak spesifik, perlu adanya perbaikan pada kuesioner bagi peneliti selanjutnya berupa kuesioner bagi peneliti selanjutnya berupa kuesioner dengan pertanyaan yang sifatnya lebih mendetail atau lebih spesifik berkaitan pada personal hygiene dengan pekerjaan sebagai petani pengguna pestisida dan pupuk dan keterbatasan lain dalam hal menilai kelengkapan penggunaan APD, penilaian penggunaan APD hanya dilakukan dengan pengisian kuesioner penelitian sehingga memungkinkan adanya data yang kurang objektif.

\section{SIMPULAN}

Berdasarkan hasil penelitian dan pembahasan dapat disimpulkan terdapat hubungan faktor risiko berikut yang bermakna secara statistik antara lain penggunaan APD, lama kontak petani, personal hygiene, jenis pestisida dan jenis upuk dengan kejadian Dermatitis Kontak pada petani di Provinsi Lampung. Tidak terdapat hubungan yang signifikan secara statistik pada masa keja dan riwayat atopi dengan kejadian Dermatitis Kontak pada petani di Provinsi Lampung. Perlu dilakukan penelitian lanjutan untuk kejadian dermatitis atopi dengan menspesifikkan kuesioner yang digunakan.

https://doi.org/10.20473/ijosh.v6i1.2017.1626

Guna, C., Lisnawaty, \& Ainurafiq. (2017). Hubungan Penggunaan Pestisida terhadap Kejadian Penyakit Dermatitis Kontak Kecamatan Mowewe Kabupaten Kolaka Timur. Jurnal Ilmiah Mahasiswa Kesehatan Masyarakat, 7, 1-12.

Indrawan, I. A., Suwondo, A., \& Lestantyo, D. (2014). Faktor-Faktor Yang Berhubungan Dengan Kejadian Dermatitis Kontak Iritan Pada Pekerja Bagian Premix Di PT. X Cirebon. Jurnal Kesehatan Masyarakat, 2(2), 110-118. Retrieved from http://ejournal-s1.undip.ac.id/index.php/jkm Irby, C. E., Yentzer, B. A., Vallejos, Q. M., Arcury, T. A., Quandt, S. A., \& Feldman, S. R. (2009). The prevalence and possible 
causes of contact dermatitis in farmworkers. International Journal of Dermatology, 48(11), 1166-1170.

Loukil, B., Mallem, L., \& Boulakoud, M. S. (2015). Study of Healthy Risks of Fertilizers on Biochemical Parameters in Workers. American-Eurasian Journal of Toxicological Sciences, 7(1), 22-25.

Marcherya, A. (2018). Faktor-faktor yang mempengaruhi kejadian dermatitis kontak akibat kerja pada pengrajin batik di griya gabovira Bandar lampung. [Skripsi]. Lampung: Fakultas Kedokteran, Universitas Lampung.

Nugroho, A., \& Sumini, S. (2015). Hubungan Perilaku Penggunaan Alat Pelindung Diri (APD) Pada Buruh Tani Dengan Kejadian Penyakit Kulit. Jurnal Ilmiah STIKES Kendal, 3(2), 36-44.

Pradananingrum, S., Lestantyo, D., \& Jayanti, S. (2018). Hubungan Personal Hygiene, Lama Kontak, Dan Masa Kerja Dengan Gejala Dermatitis Kontak Iritan Pada Pengrajin Tahu Mrican Semarang. Jurnal Kesehatan Masyarakat, 6(4), 378-386.

Retnoningsih, A. (2017). Analisis faktor-faktor kejadian dermatitis kontak pada nelayan. [Skripsi]. Semarang: Fakultas Kesehatan Masyarakat, Universitas Muhammadiyah Semarang.

Septiani, S. (2012). Faktor-Faktor Yang Berhubungan Dengan Kejadian DermatitisKontak Pada Pekerja Cleaning Servis di Kampus UIN Syarif Hidayahtullah Jakarta. [Skripsi]. Jakarta: Fakultas Ilmu Kesehatan, Universitas Islam
Negeri Syarif Hidayahtullah Jakarta.

Sharma, A., Mahajan, V. K., Mehta, K. S., Chauhan, P. S., Sharma, V., Sharma, A., ... Chauhan, S. (2018). Pesticide contact dermatitis in agricultural workers of Himachal Pradesh (India). Contact Dermatitis, 79(4), 213-217.

Sudardja, H. (2015). Hubungan antara Pajanan Pestisida Organofosfat dengan Dermatitis Kontak pada Petani Sayur di Kecamatan Lembang. [Tesis]. Depok: Universitas Indonesia.

Suryani, F. (2011). Faktor-Faktor Yang Berhubungan Dengan DermatitisKontak Pada Pekerja Bagian Processing dan Filling PT. Cosmar Indonesia Tanggerang Selatan Tahun 2011. [Skripsi]. Jakarta: Fakultas Kedoktera dan Ilmu Kesehatan, Universitas Islam Negeri Syarif Hidayatullah Jakarta.

Suryani, N. D., Martini, \& Susanto, H. S. (2017). Perbandingan Faktor Risiko Kejadian Dermatitis Kontak Iritan Antara Petani Garam Dan Petani Sawah Di Kecamatan Kaliori Kabupaten Rembang. Jurnal Kesehatan Masyarakat, 5(4), 444-455.

Thomsen, S. F. (2014). Atopic Dermatitis: Natural History, Diagnosis, and Treatment. ISRN Allergy, 2014, 1-7.

Wijaya, I. putu gilang iswara, Darmada, I., \& Ruyati, L. M. M. (2016). Edukasi dan Penatalaksanaan Dermatitis Kontak Iritan Kronis di RSUP Sanglah Denpasar Bali Tahun 2014/2015. E-Jurnal Medika, 5(8), 6-9. 